\title{
The role of C-type natriuretic peptide in rat testes during spermatogenesis
}

\begin{abstract}
Dong-Hui Huang ${ }^{1}$, Shi-Wei Zhang ${ }^{2}, \mathrm{Hu} \mathrm{Zhao}^{3}$ and Ling Zhang ${ }^{1}$
C-type natriuretic peptide (CNP) is a 22-amino acid peptide and act as a local paracrine or autocrine regulator. There is growing evidence that $C N P$ is involved in male reproductive processes. To investigate the role of $C N P$ during spermatogenesis, we measured the mRNA expression of $C N P$ and its specific membrane-bound natriuretic peptide receptor-B (NPR-B) using real-time RT-PCR in the testes of normal rats on different postnatal days. After that spermatogenesis dysfunction model induced by ornidazole was established with the aim to study the correlation of $C N P$ with spermatogenic dysfunction. Then, Sertoli cells from 18- to 22-day-old healthy male rats were cultured in the presence of different $C N P$ concentrations $\left(1 \times 10^{-6}, 1 \times 10^{-7}\right.$ and $\left.1 \times 10^{-8} \mathrm{~mol} \mathrm{I}^{-1}\right)$, and the mRNA expression levels of androgen-binding protein, inhibin $B$ and transferrin were examined at $0 \mathrm{~min}, 30 \mathrm{~min}, 1 \mathrm{~h}, 2 \mathrm{~h}, 4 \mathrm{~h}, 8 \mathrm{~h}, 12 \mathrm{~h}, 24 \mathrm{~h}$ and $48 \mathrm{~h}$. During the postnatal development of rat testes, the highest mRNA expression levels of $C N P$ and $N P R-B$ were found at postnatal $\mathrm{D}_{0}$, and the levels then declined gradually, with a second $C N P$ peak at postnatal $D_{35}$. In the ornidazole-induced infertile rat testes, $C N P$ gene expression was lower than in the uninduced rats $(\boldsymbol{P}<0.05)$, while $N P R-B$ gene expression was greater $(P<0.05)$. In cultured Sertoli cells, supplementation with $C N P$ stimulated the gene expression of androgen-binding protein/inhibin B/transferrin, particularly at $12 \mathrm{~h}$, and $1 \times 10^{-7} \mathrm{~mol} \mathrm{I}^{-1} \mathrm{CNP}$ had the highest upregulation effect. The gene expression levels of $C N P I N P R-B$ in rat testes at different postnatal stages and in infertile rat testes indicated that $C N P$ may participate in the physiology and/or pathology related to spermatogenesis. Moreover, $C N P$ regulated endocrine function in Sertoli cells. Taken together, these results showed that CNP is closely tied to spermatogenesis.
\end{abstract} Asian Journal of Andrology (2011) 13, 275-280; doi:10.1038/aja.2010.147; published online 20 December 2010

Keywords: C-type natriuretic peptide; natriuretic peptide receptor-B; Sertoli cell culture; spermatogenesis

\section{INTRODUCTION}

Natriuretic peptides belong to a family of small proteins that play a major role in the modulation of natriuresis, diuresis and vasodilatation. The natriuretic peptide family in mammals consists of three structurally related peptides: atrial natriuretic peptide $(A N P)$, brain natriuretic peptide $(B N P)$ and C-type natriuretic peptide $(C N P)$. All three members contain the conserved sequence CFGXXXDRIXXXXGLGC, where $\mathrm{X}$ is any amino acid. The flanking cysteines form a 17-amino-acid disulphide-linked ring that is required for biological activity. ${ }^{1}$ Both $A N P$ and $B N P$ bind to natriuretic peptide receptor $\mathrm{A}(N P R-A)$ and are expressed in the heart and other organs. In contrast to $A N P$ and $B N P$, which are mainly cardiovascular hormones, $C N P$ is mainly produced by extracardiac tissues to act as a local paracrine or autocrine regulator. ${ }^{2}$ Its biological effects are mediated by intracellular cyclic GMP (cGMP) accumulation via specific membrane-bound natriuretic peptide receptor B $(N P R-B)$ activation. $^{3}$

There is growing evidence that $C N P$ is involved in various reproductive processes. ${ }^{4} \mathrm{CNP}^{-/-}$mice display dwarfism, and $N P R-B^{-/-}$ mice display dwarfism, female sterility and decreased adiposity. ${ }^{5,6}$ In rats, uterine $C N P$ levels are modulated by the oestrous cycle, with the highest expression during pro-oestrus. ${ }^{7}$ For instance, an intraperitoneal infusion of oestradiol increased uterine CNP in a dosedependent fashion in ovariectomized mice. ${ }^{8}$ CNP concentrations in seminal plasma and seminal vesicle fluid were, respectively, 2000and 100000 -fold greater than those found in the porcine brain. Seminal plasma (porcine) elevates cGMP in Balb/3T3 (235-fold), NIH/3T3 and Rat-2 cells, and may function during fertilisation. ${ }^{9}$ Nielsen et al. ${ }^{10}$ examined the tissue-specific expression of proCNP and $C N P$ in extracts from 32 different porcine tissues, and the highest peptide concentrations were found in extracts from male reproductive tissues (such as the epididymis, seminal vesicles and prostate); CNP mRNA in the seminal vesicles and epididymis was 125 -fold higher than in the other tissues examined.

Therefore, we hypothesize that CNP may play a key role in spermatogenesis. To further investigate the effect of $C N P$ on spermatogenesis, the gene expression of $C N P$ and $N P R-B$ was examined by realtime quantitative RT-PCR in rat testes at different postnatal stages and in the testes of ornidazole-induced infertile rats; finally, CNP was added to Sertoli cell cultures, and its effects were observed on the endocrine function of Sertoli cells.

\section{MATERIALS AND METHODS}

\section{Materials}

The male Sprague-Dawley rats came from the Laboratory Animal Centre of Tongji Medical College (Wuhan, China). They were

${ }^{1}$ Family Planning Research Institute, Tongji Medical College, Huazhong University of Science and Technology, Wuhan 430030, China; ${ }^{2}$ Centre Laboratory, Zhongshan Hospital of Hubei Province, Wuhan 430033, China and ${ }^{3}$ Department of Human Anatomy, Tongji Medical College, Huazhong University of Science and Technology, Wuhan 430030, China Correspondence: Dr H Zhao (zhaohu@mails.tjmu.edu.cn)

Received: 10 December 2009; Revised: 16 May 2010; Accepted: 20 September 2010; Published online: 20 December 2010 
maintained under standard conditions (12 h light/12 h dark cycle; 35$60 \%$ relative humidity). Rat feed and tap water were available ad libitum.

\section{Methods}

Real-time RT-PCR. Total RNA was extracted from testes of rats at different postnatal ages $\left(\mathrm{D}_{0}, \mathrm{D}_{5}, \mathrm{D}_{10}, \mathrm{D}_{15}, \mathrm{D}_{21}, \mathrm{D}_{28}, \mathrm{D}_{35}, \mathrm{D}_{42}\right.$ and $D_{56}$ ). The day of birth was designated as postnatal $D_{0}$. Two to four rats were sampled per stage. The experiment was repeated three times to estimate expression stability. Total RNA was extracted using Trizol reagent (Invitrogen, Breda, The Netherlands) according to the manufacturer's protocol. Briefly, approximately $50 \mathrm{mg}$ of testes tissue was pipetted into $1 \mathrm{ml}$ Trizol reagent. Total RNA was reverse transcribed into first-strand cDNA using a First Strand cDNA Synthesis Kit (Toyobo, Tokyo, Japan). Each RT reaction mixture contained $3 \mu \mathrm{g}$ of total RNA, $1 \times$ RT buffer, $0.5 \mathrm{mmol} \mathrm{L}^{-1}$ of each dNTP, $1 \mu \mathrm{g}$ of oligo d(T)20, 400 IU Moloney murine leukaemia virus reverse transcriptase, $40 \mathrm{IU}$ RNasin and $\mathrm{H}_{2} \mathrm{O}$ to a final volume of $40 \mu \mathrm{l}$. The reaction mixture was incubated at $42{ }^{\circ} \mathrm{C}$ for $20 \mathrm{~min}$ and then at $99^{\circ} \mathrm{C}$ for $5 \mathrm{~min}$. Real-time RT-PCR was performed as previously described. ${ }^{11}$ The primer pairs used in RT-PCR are listed in Table 1. The amplified products were recovered from gels using a gel extraction kit. They were then used as templates for amplification of $10^{3}-10^{8}$ copies to create a standard curve.

Establishment of ornidazole-induced infertility in rats. Twenty adult male rats weighting 200-220 g were randomly divided into two groups. One group was treated with ornidazole $\left(200 \mathrm{mg} \mathrm{kg}^{-1} \mathrm{~d}^{-1}\right)$ dissolved in $0.5 \%$ carboxymethylcellulose solution, and the other group was only treated with $0.5 \%$ carboxymethylcellulose solution as control. All of the rats were treated by gastric gavage for 20 consecutive days. Treated rats were killed by cervical dislocation, and their testes were removed and decapsulated. Real-time RT-PCR was performed as described above.

Sertoli cell culture and treatment of Sertoli cells with CNP peptide. To assess the effect of CNP on Sertoli cells, CNP peptide (N8768; SigmaAldrich, St Louis, MO, USA) was added to Sertoli cell cultures. Rat Sertoli cells were isolated and cultured as previously described. ${ }^{12}$ Some Sertoli cell cultures were treated with different concentrations of CNP $\left(10^{-6}, 10^{-7}\right.$ and $\left.10^{-8} \mathrm{~mol} \mathrm{l}^{-1}\right)$, which were regarded as the experimental groups, and an untreated culture served as the control group. Each experiment was repeated three times. The cultured cells were cultured for $72 \mathrm{~h}$ before the $C N P$ was added. Treated culture cells were harvested after $0 \mathrm{~min}, 30 \mathrm{~min}, 1 \mathrm{~h}, 2 \mathrm{~h}, 4 \mathrm{~h}, 8 \mathrm{~h}, 12 \mathrm{~h}, 24 \mathrm{~h}$ and $48 \mathrm{~h}$. The mRNA levels of androgen-binding protein $(A B P)$, inhibin $B(I N H B)$ and transferrin $(T R F)$ in each sample were determined by real-time RT-PCR.

Statistical analysis. The expression level of target genes was determined by dividing the target gene expression level by $\beta$-actin expression level. The data were presented as mean \pm SD. Gene expression of
$C N P$ and $N P R-B$ in rat testes at different postnatal stages and in the testes of ornidazole-induced infertile rats was evaluated by one-way ANOVA; gene expression of $A B P, I N H B$ and TRF following stimulation by $C N P$ was analysed using general linear models-repeated measures ANOVA. Statistical analyses were performed using SPSS software version 11.5 (SPSS Inc., Chicago, IL, USA). Statistical significance was assumed at $P<0.05$.

\section{RESULTS}

\section{Specific amplification and standard curve}

Melting curve analysis demonstrated that each of the PCR products amplified a single predominant product with a distinct melting temperature, as shown in Figure 1a. The predicted length of each product was confirmed by agarose gel electrophoresis, as shown in Figure $1 \mathrm{~b}$.

The standard curves of $C N P, N P R-B$ and $\beta$-actin exhibited a linear relationship from $10^{3}$ to $10^{8}$ copies, with a correlation coefficient $>0.99$, as shown in Figure 1c and d.

\section{Gene expression of $C N P$ and $N P R-B$ in postnatal rat testes}

The gene expression of $C N P$ peaked at $\mathrm{D}_{0}$ and then declined gradually, reaching its lowest level on postnatal $\mathrm{D}_{21}$. Subsequently, its expression increased again at postnatal $\mathrm{D}_{28}$, reaching a second minor peak at postnatal $\mathrm{D}_{35}$, and declined until $\mathrm{D}_{42}$ (Figure $2 \mathrm{a}$ ). The gene expression of NPR-B also peaked at the time point just after birth $\left(D_{0}\right)$ and then declined, reaching its lowest level at postnatal $\mathrm{D}_{42}$ (Figure $2 \mathrm{~b}$ ), which was similar to the expression pattern of $C N P$, except on postnatal $D_{35}$.

Our analysis revealed that the correlation coefficient between $C N P$ and $N P R-B$ was 0.807 , which showed that the gene expression of $C N P$ and $N P R-B$ during postnatal stages had a strong positive relationship.

\section{Gene expression of $C N P$ and $N P R-B$ in rat testes subjected to} ornidazole-induced infertility

The mRNA level of CNP in the testes of ornidazole-induced infertile rats was lower than that in the testes of uninduced rats $(P=0.0401)$. However, the mRNA level of $N P R-B$ was higher than that in the uninduced rat testes $(P=0.0067)$, as shown in Table 2 .

\section{CNP can stimulate the gene expression of $A B P, I N H B$ and TRF in} cultured Sertoli cells

The gene expression levels of $A B P, I N H B$ and TRF were investigated by real-time RT-PCR quantification in cultured Sertoli cells after treatment with $C N P$. The amount of $A B P$ mRNA significantly higher $(P<0.05)$ than the control at the $8 \mathrm{~h}$ time point after $10^{-8} \mathrm{~mol} \mathrm{l}^{-1}$ CNP was added ( $P<0.05$, compared with the control group) and was significantly higher than the control $(P<0.05)$ at $8 \mathrm{~h}, 12 \mathrm{~h}$ and $24 \mathrm{~h}$ after $10^{-7} \mathrm{~mol} \mathrm{l}{ }^{-1} C N P$ was added; when $10^{-6} \mathrm{~mol} \mathrm{l}^{-1} C N P$ was present in the culture medium, the level of $A B P$ mRNA was higher than the control $(P<0.05)$ at $30 \mathrm{~min}, 1 \mathrm{~h}, 2 \mathrm{~h}, 4 \mathrm{~h}, 8 \mathrm{~h}$ and $12 \mathrm{~h}$. Among all treatments, the $A B P$ mRNA expression was most robust at the 12-h time point following $10^{-7} \mathrm{~mol} 1^{-1} \mathrm{CNP}$ treatment (Figure 3a). The

Table 1 Real-time RT-PCR primers

\begin{tabular}{lll}
\hline Gene & Forward primer & Reverse primer \\
\hline $\begin{array}{l}\beta \text {-actin } \\
\text { rCNP }\end{array}$ & 5' TCC TCC CTG GAG AAG AGC TA 3' & 5' TCA GGA GGA GCA ATG ATC TTG 3' \\
$r$ 5' CTG CTC GCG CTA CTC TCA CT 3' & 5' AAA GCA GCC TTT GGA CAA GC 3' \\
$r$ rABP & 5' ACG ACC AGC TAA GGT TAC GCA 3' & 5' CAG GAG GTC CTT TTC GCT CTC 3' \\
$r$ INHB & 5' TCC GAT ACC ACC AAG CAC AAG 3' & 5' TCA GGA AAG CTG GGA ACA CTG 3' \\
$r$ TRF & 5' CCA CTG GCT ACT ACG GGA ACT 3' & 502 CAC TCC TCC ACG ATC ATG TTG 3' \\
\hline
\end{tabular}

Abbreviations: ABP, androgen-binding protein; CNP, C-type natriuretic peptide; INHB, inhibin B; NPR, natriuretic peptide receptor; TRF, transferrin. 


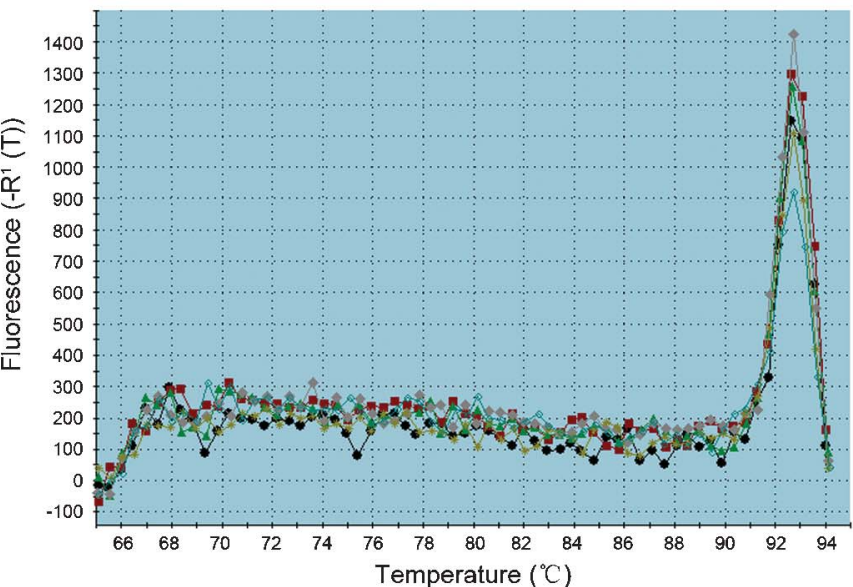

C

Amplification plots

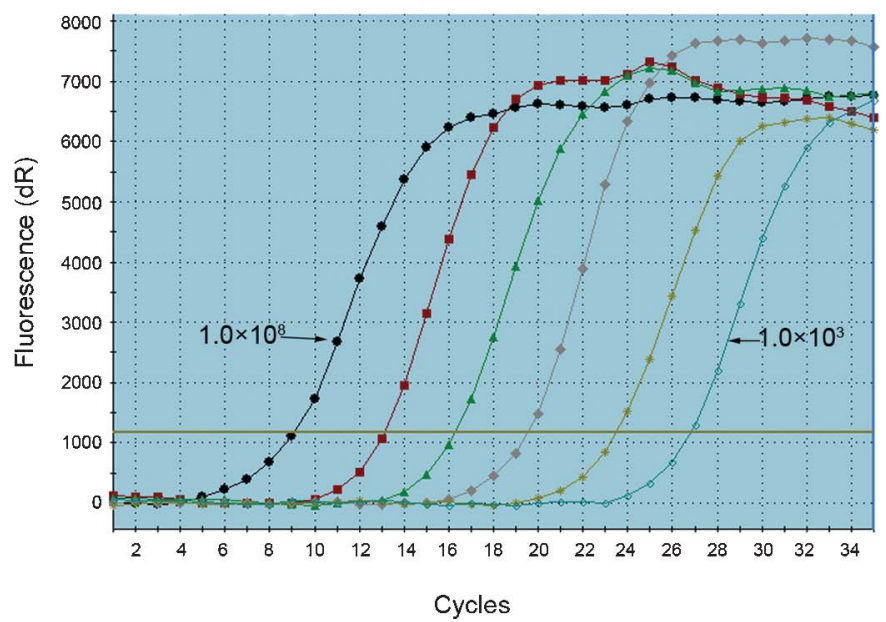

b

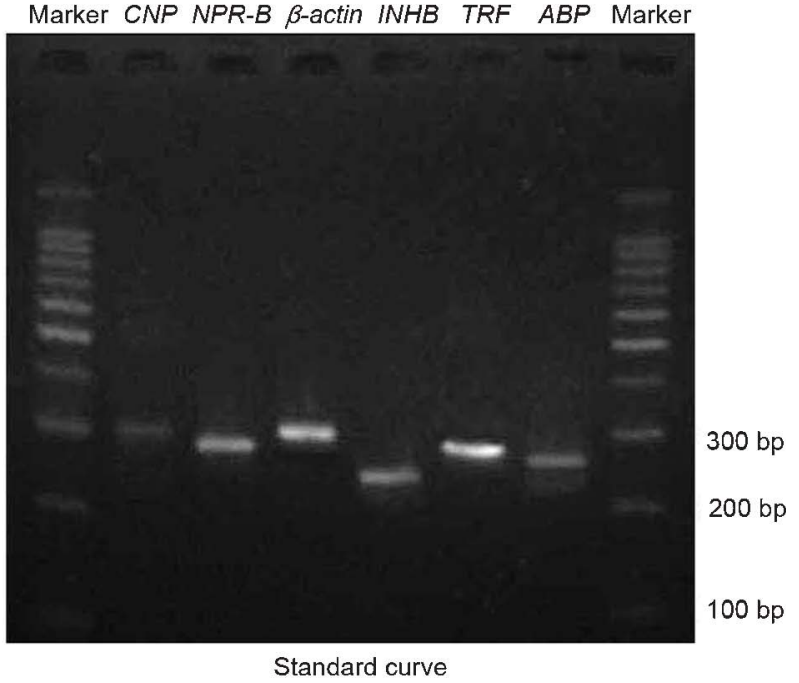

d
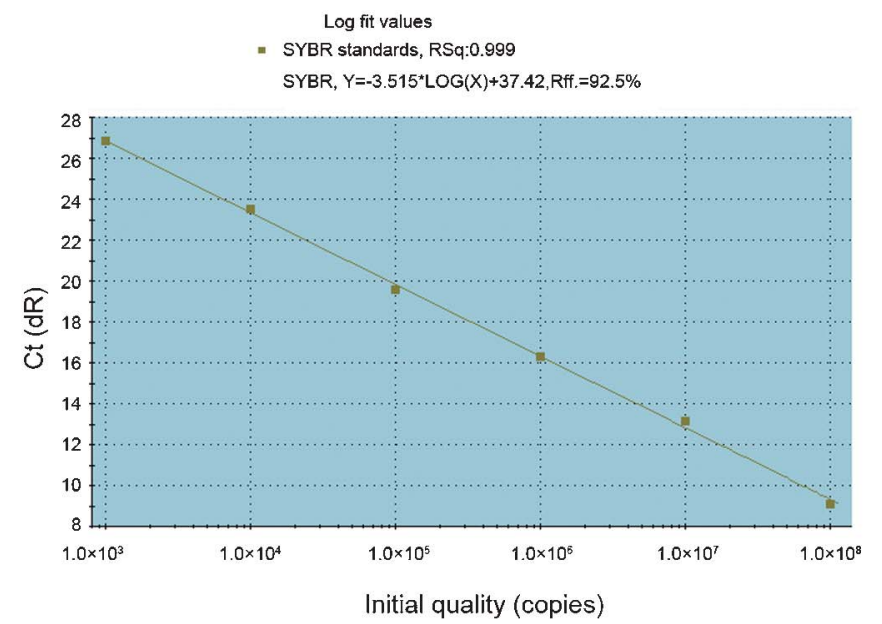

Figure 1 Specific amplification by real-time RT-PCR. (a) A melting curve analysis of a CNP amplification reaction showed a sharp, high peak of the melting temperature $\left(92.8^{\circ} \mathrm{C}\right)$, indicating the presence of a specific product that melts at this temperature; the differentially colored curve corresponds to the same colored curve in (c). (b) Agarose gel electrophoresis analysis demonstrates that this peak corresponds to a single band. (c) A plot of fluorescence from $10^{3}$ to $10^{8}$ copies of $C N P$. (d) A linear standard curve from $10^{3}$ to $10^{8}$ copies of CNP. ABP, androgen-binding protein; CNP, C-type natriuretic peptide; INHB, inhibin B; NPR B, natriuretic peptide receptor-B; TRF, transferrin.

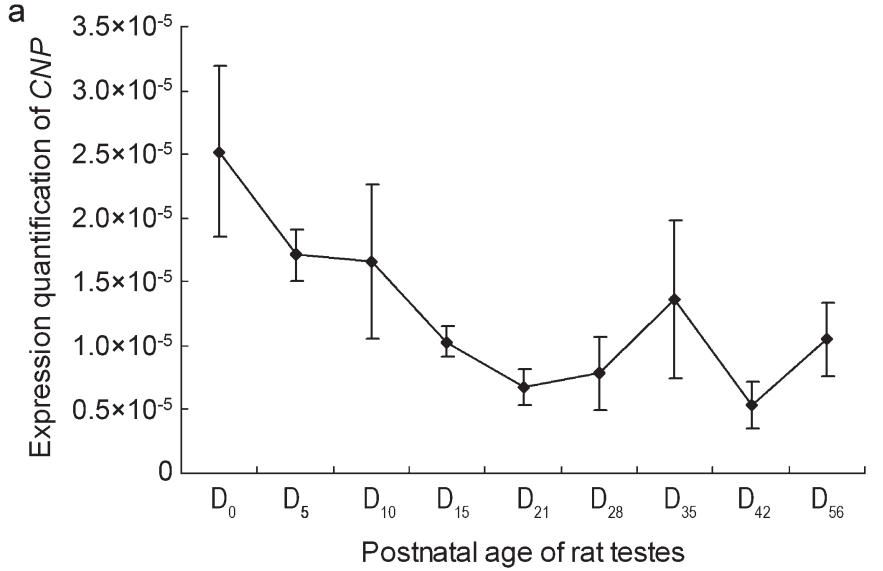

b

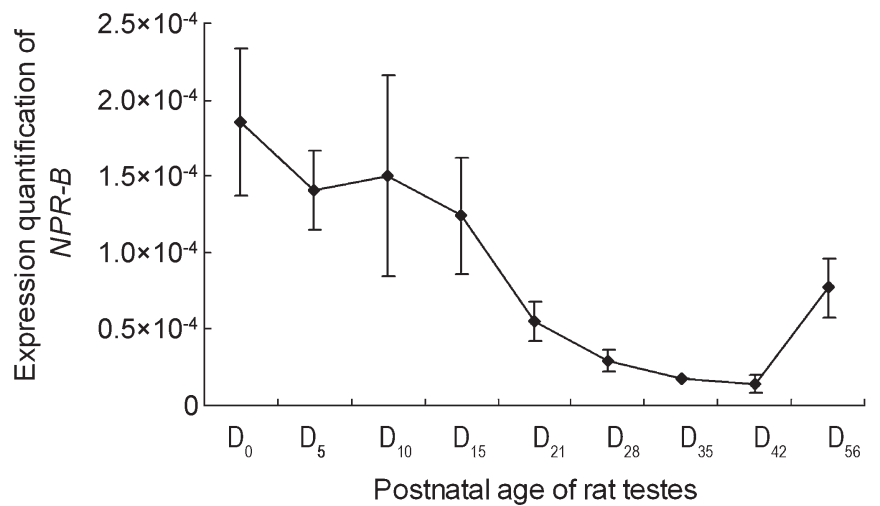

Figure 2 Gene expression of $C N P / N P R-B$ in the testes of rats at postnatal stages. The results are expressed as mean \pm s.e.m. from three different experiments. (a) Gene expression of $C N P$ in the testes of rats at postnatal stages. (b) Gene expression of NPR-B in the testes of rats at postnatal stages. CNP, C-type natriuretic peptide; NPR-B, natriuretic peptide receptor B. 
Table 2 Gene expression of $C N P$ and NPR-B in the untreated group and ornidazole group ( $\bar{x} \pm$ s.d., one-way ANOVA)

\begin{tabular}{lcc}
\hline & $C N P / \beta$-actin $\left(\times 10^{-6}\right)$ & $N P R-B / \beta$-actin $\left(\times 10^{-5}\right)$ \\
\hline Untreated group $(n=10)$ & $6.29 \pm 4.90$ & $1.87 \pm 1.07$ \\
Ornidazole group $(n=10)$ & $2.75 \pm 1.19$ & $3.16 \pm 1.06$ \\
$P$ value & 0.0401 & 0.0067 \\
\hline
\end{tabular}

Abbreviations: CNP, C-type natriuretic peptide; NPR-B, natriuretic peptide receptor B.

amount of INHB mRNAs was higher than the control $(P<0.05)$ at 8 , 12,24 and $48 \mathrm{~h}$ when $10^{-7}$ mol $1^{-1} C N P$ was added and peaked at $12 \mathrm{~h}$; there were no differences when either $10^{-8}$ or $10^{-6}$ mol $l^{-1} C N P$ was added to the cell cultures $(P>0.05$, compared with the control group; Figure $3 \mathrm{~b})$. The level of TRF mRNA was higher than the control $(P<0.05)$ at 8 and $12 \mathrm{~h}$ when $10^{-7} \mathrm{moll}^{-1} C N P$ was added and peaked at $12 \mathrm{~h}$; when $10^{-6} \mathrm{~mol} \mathrm{l}^{-1} \mathrm{CNP}$ was added, the level of TRF mRNA was higher than the control $(P<0.05)$ at $30 \mathrm{~min}, 1 \mathrm{~h}, 2 \mathrm{~h}, 4 \mathrm{~h}, 8 \mathrm{~h}, 12 \mathrm{~h}$ and $24 \mathrm{~h}(P<0.05$, compared with the control group; Figure $3 \mathrm{c})$. In summary, the gene expression levels of $A B P, I N H B$ and TRF in the $C N P$-treated Sertoli cells increased $(P<0.05$, compared with control group) and peaked after $12 \mathrm{~h}$ of treatment. Among the different concentrations examined, $10^{-7} \mathrm{~mol}^{-1} \mathrm{CNP}$ had the strongest effect on the expression of these three genes. These results imply that CNP could stimulate the endocrine function of cultured Sertoli cells.

\section{DISCUSSION}

Spermatogenesis is a complex differentiation process that creates functional sperm from an initially undifferentiated germ cell. The complete spermatogenesis cycle for rats requires 52-54 days. The process from birth to the first batch of mature spermatids released from the testes is called the first wave of spermatogenesis. In rats, there are only male germ cells (gonocytes) and Sertoli cells in the seminiferous tubules at postnatal $D_{1}$. The first 3-5 days of postnatal life, when the gonocytes gradually proliferate and move towards the seminiferous tubule basal lamina, are crucial for the successful initiation of spermatogenesis. ${ }^{13}$ The first wave of meiotic and postmeiotic germ cell development in rats occurs after postnatal $\mathrm{D}_{15} \cdot{ }^{14}$ Round, postmeiotic spermatid appear at postnatal $\mathrm{D}_{28}$ and transform into elongated spermatids at postnatal $\mathrm{D}_{40} \cdot{ }^{15}$ With the release of the first mature spermatids from the testes around postnatal $\mathrm{D}_{44}$, the first wave of spermatogenesis is completed. CNP was originally isolated as a 22-amino acid peptide from the porcine brain ${ }^{16}$ and was later found in the testes. In this study, we showed that $C N P$ and $N P R-B$ exhibited similar gene expression patterns, except for postnatal $D_{35}$, in the first wave of spermatogenesis. The $C N P$ and $N P R-B$ gene expression levels peaked at $\mathrm{D}_{0}$, which indicated that $C N P$ and $N P R-B$ have an intimate relationship with the onset of spermatogenesis. Among all of the different spermatogenic cells, the CNP mRNA level was greatest in the round sperm cells. ${ }^{17}$ In this study, the gene expression of $C N P$ reached a second peak at postnatal $D_{35}$, when the round sperm cells were abundant. The CNP mRNA level in mouse testes after birth exhibited a similar pattern to that in rat testes and was also found to increased at $\mathrm{D}_{20}$ when round sperm cells were abundant. ${ }^{17}$ These results suggest that $C N P$ may be involved in spermiogenesis.

Mammalian spermatogenesis is a highly organized event under the tight control of both endocrine and paracrine factors. If this event is not properly organized, it will result in spermatogenic dysfunction. Spermatogenesis dysfunction models have been established with the aim to study the functions of those factors involved in spermatogenesis. Ornidazole is a nitroimidazole derivative after arilin and tinida- a
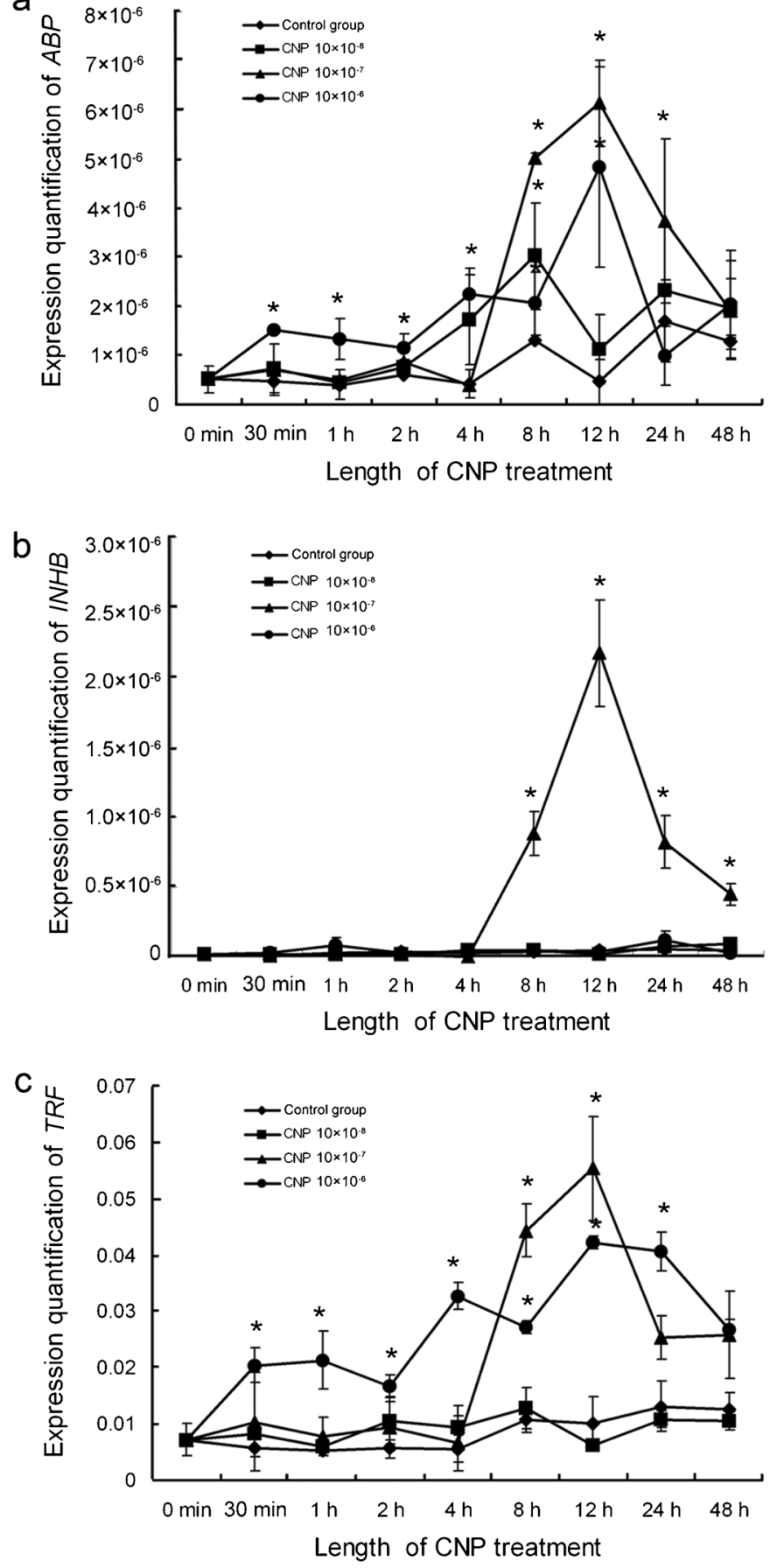

Figure 3 Gene expression of $A B P, I N H B$ and TRF in cultured Sertoli cells treated with $C N P$. (a) $A B P$ gene expression in cultured Sertoli cells treated with $C N P$. (b) INHB gene expression in cultured Sertoli cells treated with CNP. (c) TRFgene expression in cultured Sertoli cells treated with CNP. The results are expressed as mean \pm s.e.m. from three different experiments. ${ }^{*} P<0.05$, compared with the control. ABP, androgen-binding protein; CNP, C-type natriuretic peptide; INHB, inhibin B; TRF, transferrin.

zole. The antimicrobial activity of ornidazole is due to the reduction of a nitro group to a more reactive amine; this amine attacks microbial DNA, bringing about a loss of the helical structure of DNA, inducing DNA breakage, inhibiting further synthesis and ultimately causing the degradation of existing DNA. Ornidazole exerts a rapid and reversible 
antifertility effect in male rats. ${ }^{18}$ Ornidazole can reduce sperm motility, attenuate the function of spermatogenesis in testes and decrease sperm counts. However, it has no significant effect on the morphology of testes. ${ }^{19}$ One potential mechanism of ornidazole action in infertility models in rats is that spermatogenic cells may be damaged by the increased inhibition of malondialdehyde, while sperm motility may be decreased by inhibiting an energetic transferase or non-protein substance in the epididymis. ${ }^{19}$ In this study, CNP gene expression in ornidazole-treated rat testes was lower than in the untreated group, but the gene expression of $N P R-B$ was higher than that in the untreated group. This result showed that the variation of $C N P / N P R-B$ mRNA occurred earlier than the morphological differentiation of the seminiferous tubules and was accompanied by a decline of sperm motility in the ornidazole-induced infertile rat model. Therefore, one of the mechanisms through which ornidazole acts in the induction of infertility may be the up-/downregulation of $C N P / N P R-B$.

Spermatogenesis is controlled by gonadotrophins and testosterones. In males, luteinizing hormon acts on Leydig cells in the testes to produce testosterone, whereas follicle-stimulating hormone acts on the Sertoli cells to maintain their nursemaid function in spermatogenesis. A previous report showed that all three peptides could stimulate testosterone production in vivo, with significant effects at concentrations $\geqslant 1 \times 10^{-8} \mathrm{~mol} \mathrm{l}^{-1}$ of $A N P, \geqslant 1 \times 10^{-9} \mathrm{~mol} 1^{-1}$ of $B N P$ and $\geqslant 1 \times 10^{-6} \mathrm{~mol} \mathrm{l}^{-1}$ of $C N P .^{20}$ Pereira et al. ${ }^{21}$ found that ANP stimulated testosterone production in rat testis perfused in vitro but decreased luteinizing hormone-induced testosterone production, which seemed to involve the $\mathrm{C}$ receptor. As a local paracrine or autocrine regulator, CNP may be produced by most of the major endocrine glands, including the hypothalamus and the anterior pituitary. Immunocytochemical analysis demonstrated $C N P$ immunoreactivity localized to gonadotroph cells. ${ }^{22}$ Gonadotrophin-releasing hormone neuronal cell lines also express both $C N P$ and NPR-B. ${ }^{23}$ These data suggest a paracrine role for $C N P$ in the regulation of gonadotrophinreleasing hormone-secreting hypothalamic neurons and gonadotrophin-releasing hormone-responsive pituitary cells and raise the possibility that CNP may influence the neuroendocrine control of reproduction. ${ }^{24}$ Importantly, $C N P$ is also a peptide with a distinct role in male reproductive processes because both endocrine functions of the testes and penile erection are regulated by the $C N P / N P R-B$ axis. ${ }^{25}$ Xia et al. ${ }^{26}$ reported that adding the synthetic CNP-22 peptide to Sertoli cell cultures perturbed Sertoli cell tight junctions in vitro, causing the disappearance of blood-testes barrier-associated proteins (JAM-A, occludin, N-cadherin and $\beta$-catenin) from the cell/cell interface. The blood-testes barrier created by adjacent Sertoli cells and several important proteins (including $A B P, I N H B$ and $T R F$ ) synthesized by the Sertoli cells, plays a key role in spermatogenesis. ${ }^{27}$ However, the effect of $C N P$ on Sertoli cell endocrine function (such as effects on $A B P, I N H B$ and $T R F$ ) is not currently understood. In this study, $C N P$ was used to stimulate Sertoli cells cultured in vitro, and our results showed that $C N P$ could significantly stimulate Sertoli cells to express $A B P, I N H B$ and TRF, especially at a dose of $10^{-7} \mathrm{~mol}^{-1}$. In conclusion, CNP regulates blood-testes barrier dynamics and also promotes the endocrine function of Sertoli cells.

The biological effects of CNP are mediated by intracellular cGMP accumulation. In the testes, cGMP signal transduction pathways are involved in a variety of local functions, based on autocrine or paracrine effects. In particular, cGMP may influence motility in the spermatozoa, the development of testicular germ cells, the relaxation of peritubular lamina propria cells, testosterone synthesis in the Leydig cells and the dilatation of testicular blood vessels. ${ }^{28}$ Thus, CNP has a close relationship with male reproductive processes and may be the key factor in spermatogenesis.

\section{AUTHOR CONTRIBUTIONS}

$\mathrm{HDH}$ and $\mathrm{ZH}$ designed the experiment. $\mathrm{HDH}$ performed all part of experiments, analysed data and wrote the manuscript; ZSW performed experiments on correlation of CNP with spermatogenic dysfunction, and ZL performed analyses of gene expression of $\mathrm{ABP}, \mathrm{INHB}$, and TRF.

\section{COMPETING FINANCIAL INTERESTS}

The authors declare no competing financial interests.

\section{ACKNOWLEDGMENTS}

This investigation was supported by a grant from the research fund of the Tongji Medical College, Huazhong University of Science and Technology (No. 25519004) and the National Key Technologies R\&D Program for the Tenth Five-Year Plan, China (No. 2004BA720A33-1).

1 Potter LR, Yoder AR, Flora DR, Antos LK, Dickey DM. Natriuretic peptides: their structures, receptors, physiologic functions and therapeutic applications. Handb Exp Pharmacol 2009; 191: 341-66.

2 Woodard GE, Rosado JA. Natriuretic peptides in vascular physiology and pathology. Int Rev Cell Mol Biol 2008; 268: 59-93.

3 Potter LR, Abbey-Hosch S, Dickey DM. Natriuretic peptides, their receptors, and cyclic guanosine monophosphate-dependent signaling functions. Endocr Rev 2006 27: 47-72.

4 Walther T, Stepan H. C-type natriuretic peptide in reproduction, pregnancy and feta development. J Endocrinol 2004; 180: 17-22.

5 Chusho H, Tamura N, Ogawa Y, Yasoda A, Suda M et al. Dwarfism and early death in mice lacking C-type natriuretic peptide. Proc NatI Acad Sci USA 2001; 98: 4016-21.

6 Tamura N, Doolittle LK, Hammer RE, Shelton JM, Richardson JA et al Critical roles of the guanylyl cyclase $B$ receptor in endochondral ossification and development of female reproductive organs. Proc Natl Acad Sci USA 2004; 101: 17300-5.

7 Huang H, Acuff CG, Steinhelper ME. Isolation, mapping, and regulated expression of the gene encoding mouse C-type natriuretic peptide. Am J Physiol 1996; 271: H1565-75.

8 Acuff CG, Huang H, Steinhelper ME. Estradiol induces C-type natriuretic peptide gene expression in mouse uterus. Am J Physiol 1997; 273: H2672-7.

9 Chrisman TD, Schulz S, Potter LR, Garbers DL. Seminal plasma factors that cause large elevations in cellular cyclic GMP are C-type natriuretic peptides. J Biol Chem 1993; 268: 3698-703

10 Nielsen SJ, Gøtze JP, Jensen HL, Rehfeld JF. ProCNP and CNP are expressed primarily in male genital organs. Regul Pept 2008; 146: 204-12.

11 Huang DH, Zhao H, Li HG, Tian YH, Ding XF et al. Gene expression changes of urokinase plasminogen activator and urokinase receptor in rat testes at postnatal stages. Asian J Androl 2007; 9: 679-83.

12 Huang $\mathrm{DH}$, Zhao $\mathrm{H}$, Tian $\mathrm{YH}$, Xiong $\mathrm{CL}$, Wang $\mathrm{L}$, Isolation, purification and identification of Sertoli cells from rat testes. Acta Anatom Sin 2007; 28: 246-9.

13 Vigueras-Villasenor RM, Moreno-Mendoza NA, Reyes-Torres G, Molina-Ortiz D, Leon MC et al. The effect of estrogen on testicular gonocyte maturation. Reprod Toxicol 2006; 22: 513-20.

14 Killian J, Pratis K, Clifton RJ, Stanton PG, Robertson DM et al. 5alpha-reductase isoenzymes 1 and 2 in the rat testes during postnatal development. Biol Reprod 2003; 68: 1711-8.

15 Jahnukainen K, Chrysis D, Hou M, Parvinen M, Eksborg S et al. Increased apoptosis occurring during the first wave of spermatogenesis is stage-specific and primarily affects midpachytene spermatocytes in the rat testes. Biol Reprod 2004; 70: 290-6.

16 Sudoh T, Minamino N, Kenji K, Matsuo H. C-type natriuretic peptide (CNP): a new member of natriuretic peptide family identified in porcine brain. Biochem Biophys Res Commun 1990; 168: 863-70.

17 Ellis PJ, Furlong RA, Wilson A, Morris S, Carter D et al. Modulation of the mouse testes transcriptome during postnatal development and in selected models of male infertility. Mol Hum Reprod 2004; 10: 271-81.

18 Ming Y, Shang XJ, Xiong CL, Pang XB, Xiong F. Urokinase-type plasminogen activator improves the reproductive function of male rats. Zhonghua Nan Ke Xue 2006; 12: 963-7. Chinese.

19 Pang XB, Zhu Y, Li HG, Zhou H, Zhu JW et al. Effect of ornidazole on sperm in rats and its mechanism of action. Zhonghua Nan Ke Xue 2005; 11: 26-28. Chinese.

20 El-Gehani F, Tena-Sempere M, Ruskoaho H, Huhtaniemi I. Natriuretic peptides stimulate steroidogenesis in the fetal rat testes. Biol Reprod 2001; 65: 595-600. 
21 Pereira VM, Costa AP, Rosa-E-Silva AA, Vieira MA, Reis AM. Regulation of steroidogenesis by atrial natriuretic peptide (ANP) in the rat testis: differential involvement of GC-A and C receptors. Peptides 2008; 29: 2024-32.

22 McArdle CA, Olcese J, Schmidt C, Poch A, Kratzmeier M et al. C-type natriuretic peptide (CNP) in the pituitary: is CNP an autocrine regulator of gonadotropes? Endocrinology 1994; 135: 2794-801.

23 Middendorff R, Paust HJ, Davidoff MS, Olcese J. Synthesis of C-type natriuretic peptide (CNP) by immortalized LHRH cells. J Neuroendocrinol 1997; 9. 177-82.

24 Fowkes RC, McArdle CA. C-type natriuretic peptide: an important neuroendocrine regulator? Trends Endocrinol Metab 2000; 11: 333-8.
25 Kuthe A, Reinecke M, Uckert S, Becker A, David I et al. Expression of guanylyl cyclase B in the human corpus cavernosum penis and the possible involvement of its ligand C-type natriuretic polypeptide in the induction of penile erection. J Urol 2003; 169: 1918-22.

26 Xia W, Mruk DD, Cheng CY. C-type natriuretic peptide regulates blood-testes barrier dynamics in adult rat testes. Proc NatI Acad Sci USA 2007; 104: 3841-6.

27 Yan $\mathrm{HH}$, Mruk DD, Wong EW, Lee WM, Cheng CY. An autocrine axis in the testes that coordinates spermiation and blood-testes barrier restructuring during spermatogenesis. Proc Natl Acad Sci USA 2008; 105: 8950-5.

28 Middendorff R, Davidoff MS, Behrends S, Mewe M, Miethens A et al. Multiple roles of the messenger molecule cGMP in testicular function. Andrologia 2000; 32: 55-9. 